\title{
Aktivitas Pelapukan Kayu Inokulum Ganoderma boninense pada Tumpangsari Bibit Kelapa Sawit dan Talas-Talasan
}

\author{
Monica Alesia ${ }^{*}$, Suwandi Suwandi ${ }^{2}$, Suparman Suparman ${ }^{3}$ \\ *e-mail: monicaalesia@student.pps.unsri.ac.id \\ ${ }^{1}$ Ilmu Tanaman, Fakultas Pertanian, Universitas Sriwijaya, Indonesia \\ ${ }^{2,3}$ Laboratorium Fitopatologi, Program Studi Proteksi Tanaman, Fakultas Pertanian, \\ Universitas Sriwijaya, Indonesia
}

\begin{abstract}
Basal stem rot of oil palm caused by Ganoderma boninense is difficult to be controlled due to abundance of inoculum sources in the field. This study was aimed to determined effects of taro plants viz. Belitung taro (Xanthosoma sagittifolium), Bogor taro (Colocasia esculenta), and Japanese taro (Colocasia esculenta var. antiquorum) on decay of $G$. boninense inocula. Pathogen inocula as rubber wood block (RWB) colonized by G. boninense was attached with main roots of oil palm seedling and buried into soil of oil palm seedling (monoculture), mixed planting of oil palm and taro plants, or of taro plants monoculture. Burying of pathogen inocula for 3 and 6 months on taro plant resulted in 2.1 times higher decay of RWB compared than oil palm monoculture. Increasing of decay also exhibited on mixed cropping system, but it was slightly lower than on oil palm monoculture. This result suggesting the benefit of taro plants either planted under monoculture or mixed cropping to fasten decomposition of infected wood debris as an inoculum source of $G$. boninense.
\end{abstract}

Keywords: oil palm, taro plants, mixed planting, Ganoderma boninense, wood decay

\begin{abstract}
ABSTRAK
Salah satu kendala utama dalam pengendalian penyakit busuk pangkal batang pada kelapa sawit yang disebabkan oleh Ganoderma boninense adalah melimpahnya sumber inokulum penyakit di lapangan. Penelitian ini bertujuan mengetahui pengaruh tanaman talas-talasan yaitu Jepang (Colocasia esculenta var. antiquorum), talas Bogor (Colocasia esculenta), dan talas Belitung (Xanthosoma sagittifolium) terhadap pelapukan inokulum $G$. boninense. Inokulum yang berupa balok kayu karet yang dikoloni $G$. boninense diikat pada akar tanaman uji kemudian dibenamkan dalam tanah pada sistem tanam monokultur kelapa sawit, tumpang sari kelapa sawit dan talas-talasan, dan monokultur talas-talasan. Pembenaman selama 3 dan 6 bulan pada sistem monokulur talas-talasan menyebabkan pelapukan inokulum $G$. boninense yang lebih tinggi dibandingkan pada sistem monokultur kelapa sawit. Percepatan pelapukan juga terjadi pada sistem tumpangsari, tetapi sedikit lebih rendah dibandingkan monokultur kelapa sawit. Hasil ini membuktikan adanya manfaat penanaman talas-talasan baik secara monokultur ataupun sebagai tumpang sari dalam mempercepat pelapukan sumber inokulum G. boninense.
\end{abstract}

Kata Kunci: kelapa sawit, talas-talasan, tumpang sari, Ganoderma boninense, pelapuk kayu 


\section{PENDAHULUAN}

Penyakit busuk pangkal batang pada kelapa sawit disebabkan oleh cendawan Ganoderma boninense merupakan salah satu kendala utama dalam produksi kelapa sawit (Flood et.al., 2010; Lelong et.al., 2010; Liaghat et.al., 2014; Naidu, 2017; Santoso et.al., 2017; Santoso et.al., 2018). Penyakit ini dapat menyebabkan hilangnya pendapatan yang besar di negara-negara penghasil minyak sawit terkemuka di Asia Tenggara (Fowotade et.al., 2019), terutama di Indonesia dan Malaysia (Basyuni et.al., 2019; Flood et.al., 2010). $G$. boninense tergolong jamur Basidiomycota yang bersifat tular tanah. Penularan penyakit $G$. boninense dapat melalui beberapa cara, yaitu: kontak dengan akar tanaman yang sakit, basidiospora melalui udara, dan inang alternatif (Hushiarian, 2013).

Menurut Deacon (2005), jamur pelapuk dikelompokkan menjadi tiga, yaitu: jamur pelapuk putih (white rot fungi), jamur pelapuk cokelat (brown rot fungi), dan jamur pelapuk lunak (soft rot fungi). Karlinasari (2012) mengatakan bahwa sebagian besar kayu terdiri dari selulosa dan lignin. Jamur pelapuk putih akan mendegradasi selulosa dan lignin, contohnya jamur G. boninense (Ratnaningtyas, 2012; Siddiqui et.al., 2019). Sedangkan, jamur pelapuk cokelat hanya mampu merombak selulosa dan tidak mendegradasi lignin (Anastasi, 2013). Jamur pelapuk lunak menyerang kayu berkadar air dan nitrogen yang tinggi. Jamur pelapuk kayu memerlukan inang untuk mendapatkan lignin, selulosa, dan hemiselulosa sebagai makanannya sebagai sumber energi (Riah, 2014).

Upaya pengendalian penyakit BSR telah banyak dilakukan, antara lain: pengendalian teknis, biologis, dan kimiawi. Namun, upaya pengendalian tersebut sering mengalami kegagalan karena $G$. boninense memiliki kemampuan saprofitik yang tinggi dengan kisaran inang tanaman yang luas (Nildayanti, 2011).

Tanaman talas-talasan sering ditanam petani sebagai mixed planting untuk mendapatkan sumber pangan sampingan. Sejauh mana peranan talastalasan terhadap survival dan inokulum potensial G. boninense belum diketahui. Yulianti (2017), melaporkan bahwa talas dapat menekan potensi inokulum jamur akar putih (Rigidoporus microporus) dengan cara menekan pertumbuhan dan viabilitas rhizomorph. Lebih lanjut Rahmadhani (2020), menunjukkan bahwa eksudat akar talas dapat mengacaukan pertumbuhan miselium $G$. boninense. Tanaman talas dapat bersifat antimikroba, antijamur, dan antibakteri (Mengane, 2015). Pada penelitian ini, diuji aktifitas penekanan potensial inokulum $G$. boninense yang mengkoloni kayu karet.

\section{BAHAN DAN METODE}

\section{Sistem Tanam}

Sistem tanam yang diuji pada penelitian ini, yaitu: monokultur kelapa sawit, tumpang sari sawit dan talastalasan, dan monokultur talas-talasan. Talas-talasan yang digunakan adalah talas Jepang (Colocasia esculenta var. antiquorum) bersumber dari petani komersial di Malang, sedangkan talas Bogor (Colocasia esculenta (L.) dan talas Belitung (Xanthosoma sagittifolium (L.) Schott) bersumber dari petani komersial di Bogor. Sistem tanam masing-masing terdiri dari 5 tanaman uji yang digunakan sebagai ulangan yang disusun secara acak lengkap. Tanah yang digunakan dalam penelitian dikumpulkan dari lahan eksperimental Fakultas Pertanian, Universitas Sriwijaya. Ukuran polibeg adalah $30 \times 15 \mathrm{~cm}$, mengandung tanah dan pasir dengan rasio 1:1 sebanyak $5 \mathrm{~L}$. Polibeg disusun di bawah paranet dengan jarak $90 \mathrm{~cm}$ setiap jenis tanaman. 
Sebelum diinokulasi G. boninense, tanaman dibiarkan untuk tumbuh selama sebulan. Tanaman dipupuk setiap bulan menggunakan NPK 0,5\% 16-16-16 per polibeg.

\section{Inokulum G. boninense}

Isolat $G$. boninense yang digunakan adalah koleksi dari Laboratorium Fitopatologi, Departemen Hama dan Penyakit Tanaman, Fakultas Pertanian, Universitas Sriwijaya. Jamur diidentifikasi berdasarkan morfologis, molekuler dan patogenik terhadap kelapa sawit. Inokulum disiapkan dalam bentuk balok kayu karet (BKK). Ukuran BKK adalah $12 \times 5 \mathrm{~cm}$. BKK diperoleh dari petani karet di Kecamatan Gelumbang, Sumatera Selatan. BKK dibersihkan kemudian direndam dengan air selama 72 jam dan air diganti setiap 24 jam. Selanjutnya, BKK dimasukkan ke kantong plastik polypropylene, satu buah plastik polypropylene diisi sebanyak empat buah BKK, ditambahkan $25 \mathrm{ml}$ malt ekstrak dan diautoclave sebanyak 2 kali. Inokulum $G$. boninense yang berupa biakkan umur 7 hari pada MEA ditanam pada BKK yang terlebih dahulu disemprot $3 \% \mathrm{H}_{2} \mathrm{O}_{2}$. BKK diinkubasi di tempat gelap pada suhu kamar $24-27{ }^{\circ} \mathrm{C}$ selama 30 hari.

\section{Pelapukan inokulum}

Inokulum berupa BKK yang dikoloni $G$. boninense diikat pada tiga akar utama tanaman uji menggunakan Parafilm. BKK bersama akar tanaman dibenamkan sedalam $15 \mathrm{~cm}$. BKK dibongkar setelah 3 dan 6 bulan pembenaman. Pelapukan dihitung sebagai persentase kehilangan berat kering dari BKK perlakuan dibandingkan BKK tanpa kolonisasi (kontrol) yang dibenamkan sesuai dengan sistem tanam.

\section{Analisis data}

Data persentase kehilangan berat kering menunjukkan ragam yang homogen berdasarkan uji Levene. Data masing-masing sistem tanam selanjutnya dibandingkan satu sama lain menggunakan anova dan jika terdapat pengaruh yang signifikan dilakukan uji HSD pada taraf $5 \%$.

\section{HASIL DAN PEMBAHASAN}

\section{Tumpang sari dengan talas Jepang}

Balok kayu karet (BKK) yang dikoloni $G$. boninense yang diinokulasi pada tanaman kelapa sawit monokultur mengalami kehilangan berat kering atau pelapukan sebesar $29 \%$ setelah 3 bulan dan 37\% setelah 6 bulan pembenaman. Pelapukan juga terjadi pada perlakuan inokulasi terhadap tanaman talas Jepang monokultur dengan nilai pelapukan yang relatif lebih tinggi (48\% setelah 3 bulan dan $57 \%$ setelah 6 bulan) tetapi tidak berbeda nyata secara statistik. Meskipun tidak berbeda nyata secara statistik, perlakuan inokulasi pada sistem tumpang sari kelapa sawit dan talas Jepang menyebabkan pelapukan yang sedikit lebih tinggi dibandingkan perlakuan inokulasi monokultur kelapa sawit (Gambar 1). Pengujian viabilitas menunjukkan miselium $G$. boninense masih hidup mengkoloni BKK yang disampel pada medium GSM. 

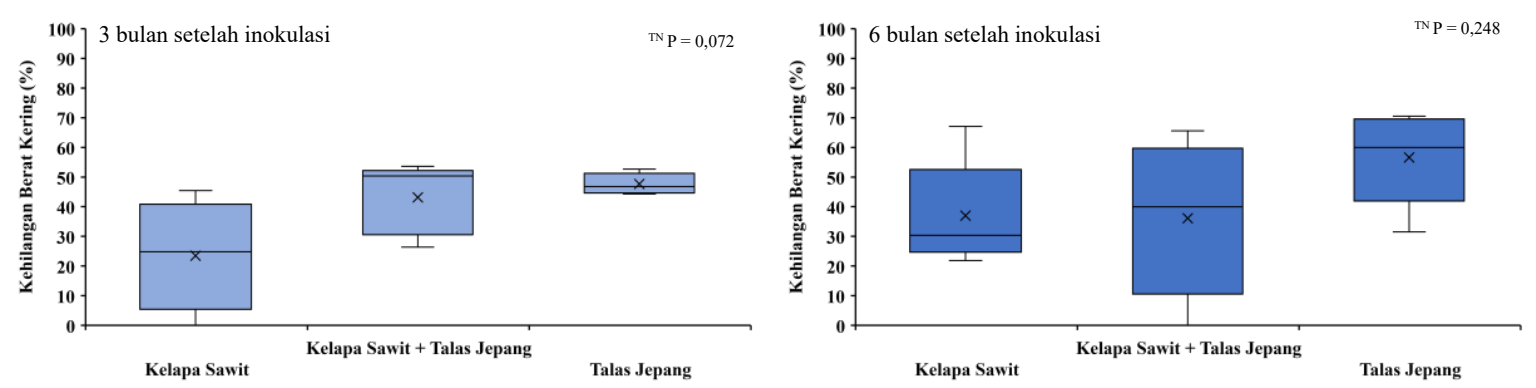

Gambar 1. Pelapukan BKK yang dikoloni Ganoderma boninense pada talas Jepang

\section{Tumpang sari dengan talas Bogor}

Respon pelapukan BKK setelah inokulasi pada talas Bogor monokultur dan tumpang sari kelapa sawit dan talas Bogor memiliki pola yang sama dengan pelapukan pada sistem talas Jepang yaitu terjadi peningkatan pelapukan pada sistem tumpang sari ataupun monokultur talas Bogor. Pelapukan pada perlakuan inokulasi terhadap tanaman talas Bogor monokultur dengan nilai pelapukan yang relatif lebih tinggi (40\% setelah 3 bulan dan 49\% setelah 6 bulan) tetapi tidak berbeda nyata secara statistik. Meskipun tidak berbeda nyata secara statistik, perlakuan inokulasi pada sistem tumpang sari kelapa sawit dan talas Jepang menyebabkan pelapukan yang sedikit lebih tinggi dibandingkan perlakuan inokulasi monokultur kelapa sawit (Gambar 2).
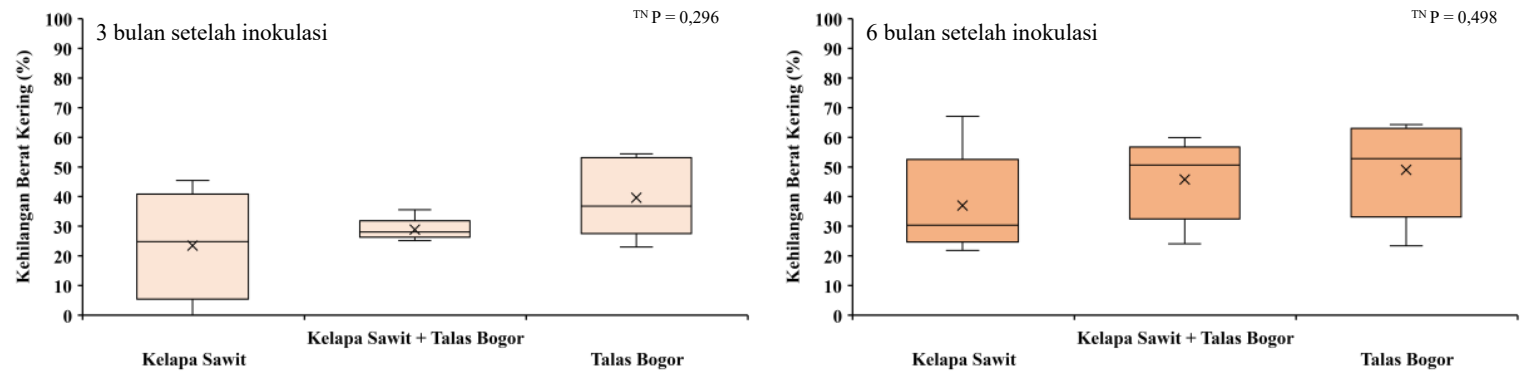

Gambar 2. Pelapukan BKK yang dikoloni Ganoderma boninense pada talas Bogor

\section{Tumpang sari dengan talas Belitung}

Berbeda halnya dengan sistem pada talas Jepang dan talas Bogor, pelapukan inokulum $G$. boninense yang berupa BKK yang dikoloni miselium mengalami peningkatan yang signifikan $(\mathrm{P}=0.002)$ jika diinokulasi pada sistem talas Belitung. Pembenaman BKK selama 3 dan 6 bulan pada talas Belitung monokultur menyebabkan pelapukan $2,1 \times$ lebih tinggi dibandingkan perlakuan kelapa sawit monokultur. Pada sistem tumpang sari dengan talas Belitung juga terjadi peningkatan pelapukan sebesar $1,2 \times$ lipat setelah 3 bulan dan 1,5× lipat setelah 6 bulan dibandingkan kelapa sawit monokultur, meskipun tidak berbeda nyata secara statistik (Gambar $3)$. 

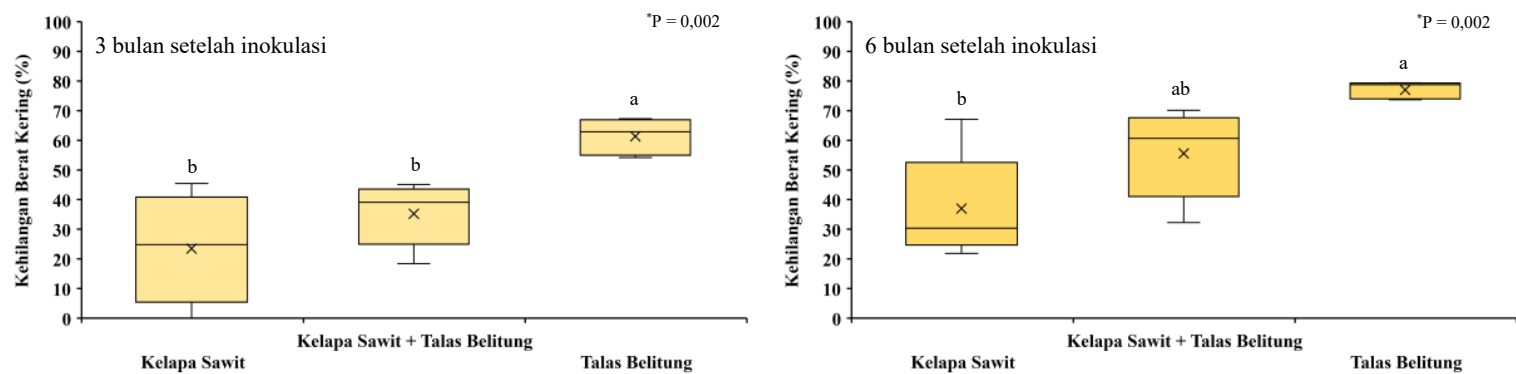

Gambar 3. Pelapukan BKK yang dikoloni Ganoderma boninense pada talas Belitung

G. boninense tergolong jamur pelapuk putih yang mampu mendegradasi lignin pada proses pelapukan kayu (Siddiqui et.al., 2019). Jamur pelapuk putih menguraikan lignin menjadi air $\left(\mathrm{H}_{2} \mathrm{O}\right)$ dan karbondioksida $\left(\mathrm{CO}_{2}\right)(\mathrm{Ohiwal}$ et.al., 2017). Jamur pelapuk putih menyerang lignin dari kayu hingga menyisakan selulosa dan hemiselulosa, hal ini mengakibatkan kandungan lignin pada kayu berkurang. Lignin memiliki peran dalam penyedia kekuatan fisik pohon. Oleh karena itu, kayu yang terserang oleh jamur pelapuk putih akan berubah menjadi rapuh seperti spon. Lignin sukar didegradasi, degradasi lignin membutuhkan enzim ekstraseluler (Perez et.al., 2002). Perombakan lignin oleh $G$. boninense terjadi melalui aktivitas enzim-enzim perombak lignin (ligninase) yang diproduksi secara ekstraseluler yaitu mangan peroksidase (MnP) dan lakkase (Lac) (Ho et.al., 2020).

Hasil penelitian menunjukkan bahwa $G$. boninense dapat menyebabkan pelapukan kayu karet yang mengakibatkan kehilangan berat kering tergantung dari sistem pertanaman. Pada pembenaman 3 bulan, pelapukkan tertinggi terjadi pada perlakuan monokultur talas Belitung sebesar 67\% dan terendah pada perlakuan monokultur kelapa sawit sebesar 11\%. Sedangkan, pada 6 bulanan pembenaman pada inang utama yaitu kelapa sawit terjadi pelapukan yang paling rendah dengan rata-rata $37 \%$ dibandingkan perlakuan talas-talasan yang pelapukkannya $2,1 \times$ lipat lebih tinggi (79\%). Hal ini membuktikan bahwa adanya manfaat penanaman talas-talasan baik secara monokultur ataupun sebagai tumpang sari dalam mempercepat pelapukan sumber inokulum $G$. boninense setelah 3 dan 6 bulan inokulasi. Pelapukan inokulum $G$. boninense pada inang utama kelapa sawit pada penelitian ini sebanding dengan yang dilaporkan oleh Rahmadhani (2020). Pada penelitian ini tumpang sari dengan talas Belitung menyebabkan pelapukan yang sedikit meningkat dibandingkan dengan sistem monokultur kelapa sawit. Berbeda halnya dengan penelitian Rahmadhani (2020) yang melaporkan pelapukan pada sistem tumpang sari dengan talas Belitung yang lebih rendah. Perbedaan hasil ini diduga karena infeksi tidak terjadi pada penelitian Rahmadhani (2020) sehingga jamur hanya hidup sebagai saprofit.

Tanaman talas mengandung senyawa golongan steroid, terpenoid, alkaloid, flavonoid, dan peptida. Alkaloid dan flavonoid dapat mengakibatkan kerusakan dan kebocoran pada membran sel pada jamur (Freisleben dan Anna, 2014; Abrahao et.al., 2016). Terpenoid dan steroid memiliki fungsi sebagai antifungi dengan cara menghambat pertumbuhan fungi, baik melalui membran sitoplasma maupun disfungsi mitokondria (Freisleben dan Anna, 2014). Peptida memiliki fungsi sebagai antifungi dengan cara merusak membran sel. Peptida akan berinteraksi dengan membran dinding sel, sehingga menyebabkan pengeluaran kalium dan 
kebocoran nukleotida (Li et.al., 2016). Karena sifat tanaman talas-talasan yang bersifat antifungi inilah diduga dapat mempercepat pelapukan pada BKK karena $G$. boninense tidak mendapatkan makanan atau nutrisi selain dari BKK. Namun, mekanisme tanaman talastalasan dalam mempercepat pelapukan belum diketahui dan perlu kajian lebih lanjut. Percepatan pelapukan oleh tanaman talas tersebut menyebabkan berkurangnya potensi inokulum karena berkurangnya sumber nutrisi yaitu lignin yang digunakan $G$. boninense untuk menginfeksi dan bertahan hidup. Hal ini sesuai Yulianti (2017) yang mengatakan bahwa tanaman talas-talasan dapat menekan potensi inokulum jamur akar putih yang terjadi melalui aktivitas percepatan pelapukan kayu karet. Hal ini berdampak positif, karena dapat mengurangi laju infeksi pada tanaman kelapa sawit (Data menunjukkan pelapukan pada perlakuan talas monokultur lebih tinggi dibandingkan perlakuan sawit). Manfaat talas ini dalam melapukkan inokulum dapat dikembangkan lebih lanjut untuk membersihkan kayu atau sumber penular $G$. boninense di lapangan yaitu sebagai cleaning crop setelah replanting kelapa sawit.

\section{KESIMPULAN}

Pembenaman selama 3 dan 6 bulan pada sistem monokulur talastalasan menyebabkan pelapukan inokulum $G$. boninense yang lebih tinggi dibandingkan pada sistem monokultur kelapa sawit. Percepatan pelapukan juga terjadi pada sistem tumpang sari, tetapi sedikit lebih rendah dibandingkan monokultur kelapa sawit.

\section{Ucapan Terima Kasih}

Penelitian didanai skim Penelitian

Dasar Unggulan Perguruan Tinggi dengan Kontrak Penelitian Nomor:
150/SP2H/LT/DRPM/2021 yang diketuai oleh Dr. Suwandi.

\section{DAFTAR PUSTAKA}

Abrahao A, Heloisa MBF, Janiere P, Debora RPM, Gabriela L, Jose MBF, Jose P, Edeltrudes OL. (2016). In vitro anti-Candida activity and mechanism of action of the flavonoid isolated from Praxelis clematidea against Candida albicans species. Journal of Applied Pharmaceutical Science, 6, 66-69.

DOI: 10.7324/JAPS.2016.600111.

Anastasi, A., Tigini, V., Varese, G.C., (2013). The Bioremediation potential of different ecophysiological groups of fungi. In: E.M. Goltapeh et al. (eds.), Fungi as Bioremediators, Soil Biology 32, Springer-Verlag Berlin Heidelberg, 29-42.

Basyuni, M, A Purba, L A P Putri, R Hayati, D Chalil, dan I Syahputra. (2019). Bioinformatics analysis of predicted Ganoderma boninense from oil palm (Elaeis guineensis). Journal of Physics, 1235, 11-17. DOI: $10.1088 / 1742-$ 6596/1235/1/012071.

Deacon, J. (2005). Fungal biology, A textbook. Cornwell, England: Blackwell Publishing.

Flood, J. et al. (2010). Some latest R \& $\mathrm{D}$ on Ganoderma diseases in oil palm. In Proceedings of the Second International Seminar Oil Palm Diseases-Advances in Ganoderma Research and Management, Yogyakarta, Indonesia, 31st May 2010:1-21.

Fowotade, S. A., Yusof, N.A., Abdullah, J., Sulaiman, Y. dan Abd Rahman, S.F. (2019). Enhanced electrochemical sensing of secondary metabolites in oil palms for early detection of Ganoderma 
boninense based on novel nanoparticle-chitosan

functionalized multi-walled carbon nanotube platform. Sensing and Bio-Sensing Research, 23:100-274. DOI: $10.1016 /$ j.sbsr.2019.100274.

Freiesleben, S.H. dan Jäger, A. (2014). Correlation between plant secondary metabolites and their antifungal mechanisms-A review. Medicinal and Aromatic Plants 3, 1-6.

Ho, P.Y., Namasivayam, P., Sundram, S. dan Ho, C.L. (2020). Expression of Genes Encoding Manganese Peroxidase and Laccase of Ganoderma boninense in Response to Nitrogen Sources, Hydrogen Peroxide and Phytohormones. Genes, 11(11), 1263.

Hushiarian, R., Yusof, N.A. dan Dutse, S.W. (2013). Detection and control of Ganoderma boninense: strategies and perspectives. SpringerPlus, 2(1), 1-12.

Karlinasari, L., Sabed, M., Wistara, N.J., Purwanto, A. dan Wijayanto, $\mathrm{H}$. (2012). Karakteristik spektra absorbansi NIR (Near Infra Red) spektroskopi kayu Acacia mangium WILLD pada 3 umur berbeda. Jurnal Ilmu Kehutanan, 6(1), 4552.

Lelong, C.C., Roger, J.M., Brégand, S., Dubertret, F., Lanore, M., Sitorus, N.A., Raharjo, D.A. dan Caliman, J.P. (2010). Evaluation of oil-palm fungal disease infestation with canopy hyperspectral reflectance data. Sensors, 10(1): 734-747. DOI: 10.3390/s 100100734.

Li L, Sun J, Xia S, Tian X, Cheserek MJ, Le G. (2016). Mechanism of Antifungal Activity of Antimicrobial Peptide APP, A CellPenetrating Peptide Derivative, Against Candida albicans: Intracellular DNA Binding and Cell Cycle Arrest. Applied microbiology and biotechnology, 100, 32453253.

Liaghat, S., Ehsani, R., Mansor, S., Shafri, H.Z., Meon, S., Sankaran, S. dan Azam, S.H. (2014). Early detection of basal stem rot disease (Ganoderma) in oil palms based on hyperspectral reflectance data using pattern recognition algorithms. International Journal of Remote Sensing, 35(10), 3427-3439. DOI: 10.1080/01431161.2014.903353.

Mengane SK. (2015). Antifungal activity of the crude extracts of Colocasia esculenta leaves in vitro on plant pathogenic fungi. Int Res $J$ Pharm, 6, 713-714.

Naidu, Y., Siddiqui, Y., Rafii, M.Y., Saud, H.M. dan Idris, A.S. (2017). Investigating the effect of white-rot hymenomycetes biodegradation on basal stem rot infected oil palm wood blocks: Biochemical and anatomical characterization. Industrial Crops and Products, 108, 872-882.

Nildayanti. (2011). Peran Bakteri Kitinolitik dan Fungi Mikoriza Arbuskular dalam Pengendalian Busuk Pangkal Batang Kelapa Sawit [Tesis]. Bogor: Sekolah Pasca Sarjana, Institut Pertanian Bogor.

Ohiwal, M., Widyastuti, R. dan Sabiham, S. (2017). Populasi Mikrob Fungsional pada Rhizosfer Kelapa Sawit di Lahan Gambut Riau. Jurnal Ilmu Tanah dan Lingkungan, 19(2), 74-80.

Perez J, Muñoz-Dorado J, De-la-Rubia T, Martínez J. (2002). Biodegradation and biological treatments of cellulose, hemicellulose and lignin: an overview. Int Microbiol, 5, 5363.

Rahmadhani, T.P., Suwandi Suwandi, Suparman Suparman. (2020). Growth responses of oil palm seedling inoculated with 
Ganoderma boninense under competition with edible herbaceous plants. Journal of Scientific Agriculture, 4, 45-49. DOI: 10.25081/jsa.2020.v4.6231.

Ratnaningtyas, N.I. dan Samiyarsih, S. (2012). Karakterisasi Ganoderma spp. di Kabupaten Banyumas dan Uji Peran Basidiospora dalam Siklus Penyakit Busuk Batang. Majalah Ilmiah Biologi BIOSFERA: A Scientific Journal, 29(1), 36-41.

Riah. (2014). Keaweatan Alami Kayu Meranti Merah (Shorea leprosula) Hutan Alam dan Hutan Tanaman dari Serangan Jamur Pelapuk Kayu. Jurnal Hutan Lestari, 2(1).

Santoso, H., Tani, H., dan Wang, X. (2017). Random Forest classification model of basal stem rot disease caused by Ganoderma boninense in oil palm plantations. International Journal of Remote Sensing, 38(16), 4683-4699. DOI: $10.1080 / 01431161.2017 .1331$ 474.

Santoso, H., Tani, H., Wang, X., Prasetyo, A. E., \& Sonobe, R. (2018). Classifying the severity of basal stem rot disease in oil palm plantations using WorldView-3 imagery and machine learning algorithms. International Journal of Remote Sensing, 00(00), 1-23. DOI:10.1080/01431161.2018.1541 368.

Siddiqui, Y., Surendran, A. dan Fishal, E.M.M. (2019). Inhibition of Lignin Degrading Enzymes of Ganoderma spp.: An Alternative Control of Basal Stem Rot Disease of Oil Palm. Int. J. Agric. Biol, 3, 523-530.

Yulianti, Sika, Suwandi Suwandi, dan Nurhayati Nurhayati. (2017). Kemampuan tumbuhan terna dalam menekan potensi inokulum Rigidoporus microporus. Jurnal
Fitopatologi Indonesia, 13, 81-88. DOI: 10.14692/jfi.13.3.81. 